\title{
Changes of Land Use and Land Cover with the Diversity of Fishes, Aquatic Plants, and Bird's Species at Wetland Ecosystem
}

\author{
Mohammad Zahangeer Alam $\mathbb{D}^{1}$, Md. Abdullahil Baki Bhuiyan $\mathbb{D}^{2}{ }^{2}$ \\ Hasan Muhammad Abdullah $\mathbb{D D}^{3}{ }^{3}$ Suma Rani Ghosh, ${ }^{1}$ Mohammad Maksudul Hassan, ${ }^{4}$ \\ Ruzina Akter, ${ }^{5}$ M. Rokonuzzaman $\mathbb{D}^{6},{ }^{6}$ and Mohammad Shah Alam $\mathbb{D}^{7}$ \\ ${ }^{1}$ Department of Environmental Science, Faculty of Agriculture, \\ Bangabandhu Sheikh Mujibur Rahman Agricultural University (BSMRAU), Gazipur-1706, Bangladesh \\ ${ }^{2}$ Department of Plant Pathology, Faculty of Agriculture, \\ Bangabandhu Sheikh Mujibur Rahman Agricultural University (BSMRAU), Gazipur-1706, Bangladesh \\ ${ }^{3}$ Department of Agroforestry and Environment, Faculty of Agriculture, \\ Bangabandhu Sheikh Mujibur Rahman Agricultural University (BSMRAU), Gazipur-1706, Bangladesh \\ ${ }^{4}$ Department of Environmental Science, Faculty of Agriculture, Bangladesh Agricultural University, \\ Mymensingh-2202, Bangladesh \\ ${ }^{5}$ Department of Criminology and Police Science, Mawlana Bhashani Science and Technology University, Santosh, \\ Tangail-1902, Bangladesh \\ ${ }^{6}$ Department of Agricultural Extension and Rural Development, Faculty of Agriculture, \\ Bangabandhu Sheikh Mujibur Rahman Agricultural University (BSMRAU), Gazipur-1706, Bangladesh \\ ${ }^{7}$ Department of Anatomy and Histology, Bangabandhu Sheikh Mujibur Rahman Agricultural University, \\ Gazipur-1706, Bangladesh
}

Correspondence should be addressed to Mohammad Zahangeer Alam; mohammad.alam@wsu.edu

Received 15 June 2021; Accepted 5 November 2021; Published 8 December 2021

Academic Editor: Claudio Cameselle

Copyright (c) 2021 Mohammad Zahangeer Alam et al. This is an open access article distributed under the Creative Commons Attribution License, which permits unrestricted use, distribution, and reproduction in any medium, provided the original work is properly cited.

\begin{abstract}
Bangladesh is rich in wetland biodiversity with aquatic plants, fishes, and birds. Mohanganj Upazila is known as the capital of lower Bangladesh. The present study focuses on the changes of land use and land cover (LULC) with a diversity of species that are being least concerned (LC), vulnerable (VU), and endangered (EN). Over the last two decades, the wetland species of Mohanganj were gradually declined. Our results showed that 19 fish, 4 aquatic plants, and 7 bird species were LC in 2015. Among the fish and aquatic plant species, 6 fish species (Wallago attu, Ompok pabda, Channa punctate, Chitala chitala, Salmostoma phulo, and Corica soborna) and 2 aquatic plant species (Nymphaea nouchali and Nymphaea lotus) were VU during the dry and rainy season of 2017 and 2019, respectively. In the dry season of 2019, 4 fish species (W. attu, O. pabda, C. punctate, and Ch. chitala), 2 aquatic plant species (N. nouchali and N. lotus), and 7 bird species (Anas platyrhynchos, Ardeola grayii, Gyps bengalensis, Alcedo atthis, Phalacrocorax fuscicollis, Porphyrio porphyria, and Larus ridibundus) were EN. Among the species, W. attu, N. nouchaii, $G$. bengalensis, P. porphyria, and L. ridibundus were extremely endangered categories. Changes in LULC, the establishment of settlements for the increasing population, indiscriminate use of pesticides, environmental pollutions, and climate change are the potential reasons for declining trends of wetland biodiversity. Stern actions on land use policy, expansion of organic agriculture, bioremediation of industrial effluents, and adoption of sustainable environmental policies should be taken by the Government of Bangladesh for immediate conservation of wetland biodiversity.
\end{abstract}




\section{Introduction}

Wetlands are one of the key natural resources where diversified species live. These wetlands provide natural ecosystem services, such as water, fish, edible food, wood, energy, and recreational activities to human beings. Marsh, fen, and peatland are the most productive wetland ecosystem in the world [1]. Wetlands connect land with water, which may be permanent or temporary, static or flowing, and fresh or brackish, including the areas of marine water. Wetland resources are key to sustainable livelihoods through the process of nutrient and carbon cycles, hydrological cycles, soil-forming dynamics, natural-resourcedriven livelihoods, and reducing the vulnerability of crops to pests, disease, drought, and flooding $[2,3]$. Sundarbans is the most recognized saltwater wetland with a mangrove forest in Bangladesh [4]. However, Tanguar Haor and Hakaluki Haor are the most remarkable freshwater wetland ecosystems $[4,5]$.

Sundarbans is exclusively important for the home of the critically endangered Royal Bengal Tiger and Freshwater dolphins [6]. About 137 freshwater fish species and 558 animal species are available in Tanguar and Hakaluki haor, respectively. Out of 1218 vertebrate species in Bangladesh, about 691 species live in wetlands [6]. Bangladesh is rich in wetland biodiversity with 280 freshwaters, 49 amphibians, 160 reptiles, 208 aquatic birds, and 490 marine species present in different wetland ecosystems [7-10]. Most of the species in wetland ecosystems are categorized as rare, endangered, threatened, and vulnerable [11].

The biodiversity of the wetland ecosystem varies from region to continent. It encompasses a range of living things with different habitats. Wetlands are the most valuable ecosystems in the world. It is the rich source of global biodiversity within the major climatic belts due to the evolved collection of fishes, animals, and plants [12]. The wetland ecosystems are surrounded by water either fresh or salty [13]. However, land-based terrestrial ecosystems are found on lands such as forests or grasslands [14]. Therefore, the challenges of these ecosystems are very different.

Globally, there are many major challenges of wetland habitats, such as inadequate social and political capacity, climate change, and insufficient planning by the government to the conservation of species [15]. In Bangladesh, the vulnerability of wetland species and ecosystem services has increased due to the agricultural land conversion, changes in land use and land cover (LULC), deforestation, climate change, harvesting of natural resources, and the introduction of alien species [16]. The depletion of the wetland biodiversity also depends on the wetland type and ecosystem services. Most of these challenges can be overcome through the development of a plant or animal's distinctive behavior [9].

Although some species in wetland ecosystems are capable of overcoming environmental threats, the majority of the species are vulnerable to the changing environment in the world $[1,17]$. Sedimentation and flooding are the major causes of reducing species diversity in the wetland ecosystem $[18,19]$. Recently, some species disappeared, such as
Catarina Pupfish, Sumatran Rhino, Chinese paddlefish, Yangtze giant softshell turtle, Indian Cheetah, Spix Macaw, and Indochinese tiger from the wetland habitats throughout the world $[10,20]$.

Globally, a quarter of mammals and aquatic species in wetland ecosystems are threatened by human activities over the last 100 years $[21,22]$. In Bangladesh, wetland species are exposed to rapid degradation due to high population density, unplanned industrialization and urbanization, habitat destruction, wastewater disposal, and natural hazards [23]. Thus, the biodiversity of wetland ecosystems in Bangladesh has been lost over the last two decades, which creates negative impacts on natural resources, human livelihood, and sustainability [21].

Mohanganj is one of the wetland-based Upazila under the Netrokona district. Netrokona is situated in the northern part of Bangladesh, near the Meghalayan border of India. There are five main rivers, such as Kangsha, Someshawri, Dhala, Magra, and Teorkhali, passing through Netrokona. This district is also a part of the Surma-Meghna River System. All wetlands in Mohanganj are connected with the famous Kangsha River. Recently, wetland species at Mohanganj are remained in an extremely risky condition due to the diverse human activities as well as changes of LULC. The study of LULC, an important determinant of biodiversity in Mohanganj, is yet to be known. Therefore, this study was undertaken to unveil the LULC of Mohanganj Upazila over the last two decades, to know the wetland ecosystems of this Upazila over the last 5 years to determine the biodiversity changes and to assess the environmental threats using public perception.

\section{Materials and Methods}

2.1. Study Areas. The survey was conducted at nine wetland ecosystems (Nagadura, Dingaputa, Chadra, Sonapeti, Aizda, Firail, Nader, Sonarthal, and Khalaura) at Mohanganj Upazilla $\left(24^{\circ} 52^{\prime} 21^{\prime \prime} \mathrm{N} 90^{\circ} 58^{\prime} 32^{\prime \prime} \mathrm{E}\right)$ under the District of Netrokona, Bangladesh. The sites of the study are illustrated in Figure 1.

2.2. Land Use and Land Cover (LULC) Changes. Changes in agriculture, trees, water bodies, and other lands in Mohanganj Upazilla were analyzed through QGIS SAGA using cross-classification and tabulation tools during 2000, 2010, 2018, and 2020 (Figures 2(a)-2(f)). The procedure of LULC changes is highlighted in Figure 3.

2.3. Inception Meeting with Wetland Communities. An inception meeting was arranged at the office of the Department of Agricultural Extension (DAE) of Mohanganj Upazila. This meeting was conducted with community people, visitors, government officials, scientists, and fishermen who have been living in the surrounding areas of these wetland ecosystems for the last 20 years. The government officials were concerned regarding the effects of environmental threats on wetland biodiversity. In the 


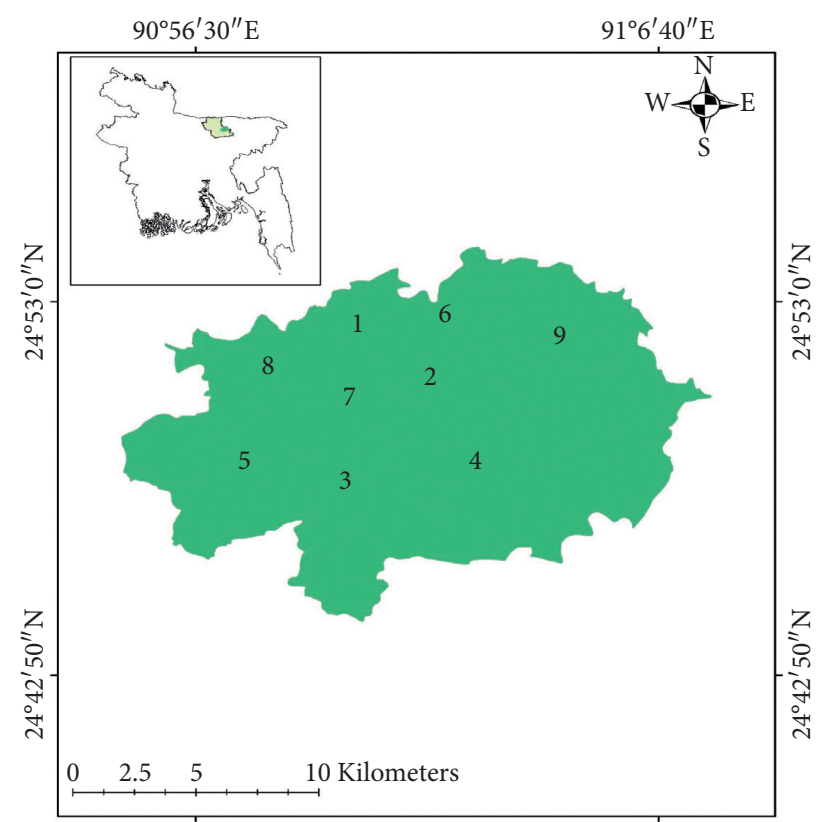

$90^{\circ} 56^{\prime} 30^{\prime \prime} \mathrm{E}$
(1) Nagadura
(6) Firail
(2) Dingaputa
(7) Nader
(3) Chadra
(8) Sonarthal
(4) Sonapeti
(9) Khalaur
(5) Aizda

Figure 1: Sites of study area on different wetland biodiversity.

meeting, the participants were briefed with the criteria of species to be considered as least concern (LC), vulnerable (VU), and endangered (EN) according to the guidelines of the International Union for the Conservation of Nature (IUCN). According to IUCN, a species was considered as vulnerable (VU) when it was likely to become endangered within the foreseeable future, a species was considered as endangered (EN) when it was at risk of extinction, and a species was considered as least concern (LC) when it has been categorized as a visible species.

2.4. Questionnaire. A survey questionnaire was developed considering the qualitative and quantitative data of least concern (LC), vulnerable (VU), and endangered (EN) species of fish, aquatic plants, and birds in the wetland ecosystem of Mohanganj. In addition, properties of all wetland ecosystems such as wetland area, water life, and topography, type of wetland, major crops, and causes of water body reduction are highlighted in Table 1 .

2.5. Data Collection Procedure. We interviewed 50 people from each location. Among these, on average 10-12 people were women, and the rest of the people were men; both of them were 40-60 years old. The interviewees were involved in diverse professions, such as fishing, boating, industry, government officials, and research, whose average level of education was primary to graduate.
2.6. Record of Least Concerning, Vulnerable, and Endangered Species of Wetland Ecosystems. All the fish, aquatic, and birds species in the wetland ecosystems of Mohanganj were recorded during summer/raining (May to September) and winter/dry season (November to February) in 2015, 2017, and 2019. The species were recorded as LC, VU, and EN following the guidelines of [24] (Figure 4). Seasonal changes of fish, aquatic plant, and bird species categories (LC, VU, and $\mathrm{EN}$ ) were recorded.

2.7. Binomial Probability. Binomial probability indicated the outcome of success or failure with multiple trials in an experiment. In this study, we used binomial probability to determine which species were more or less EN than other species. The probability of a species being EN was 0.1955 (41 EN species out of 210 total species). Binomial distribution was calculated using Minitab (Version 9.2).

2.8. Record of Major Environmental Threats. Major environmental threats and their impacts on fish, aquatic plants, and bird species in the wetland ecosystem services were noted based on the public perception to achieve sustainable development goals in Bangladesh.

2.9. Statistical Analysis. Seasonal variations of LC, VU, and EN fishes, aquatic plants, and bird species were analyzed in 2015, 2017, and 2019 using MS-Excel 2013. Land use and land cover (LULC) changes were analyzed through QGIS SAGA using a cross-classification and tabulation tool.

\section{Results}

3.1. Properties of Wetlands. The area under the wetland ecosystem was varied in winter and rainy seasons. In the rainy season of 2019, the wetland areas of Nagadura, Dingaputa, Chadra, Sonapeti, Aizda, Firail, Nader, Sonarthal, and Khalaura were 26, 46539, 90, 65, 59, 63, 105, 65, and 66 hectares, respectively, which was about $20 \%$ reduced during the winter/dry season. Rainfall was the main source of water in all wetlands. The topography of the surveyed wetland was flat to medium high. Rice was the main crop that was irrigated by using the water of these wetlands during the winter season. However, the irrigation during the rainy season was rain-fed (Table 1).

3.2. Land Use and Land Cover (LULC) Changes. Total area with agricultural crops was 2905.8, 7566.3, 3465.8, 5789.0, 4035.4, and 9653.5 ha in 2000 (Nov), 2010 (Nov), 2018 (Dec), 2000 (Feb), 2010 (Feb), and 2020 (March), respectively. The agricultural cropland area was increased from 2000 to 2010 in November. In contrast, cropland was decreased from 2000 to 2010 in February. Overall, increases in agricultural cropland were 19.3 to $66.7 \%$ from 2000 (November) to 2020 (March) (Figures 2(a)-2(f) and Table 2). Areas covered with trees were 5551.2, 4038.93,8876.25, 8228.88, 3384.99, and 9810.63 ha in 2000 (November), 2010 (November), 2018 (December), 2000 (February), 2010 (February), and 2020 

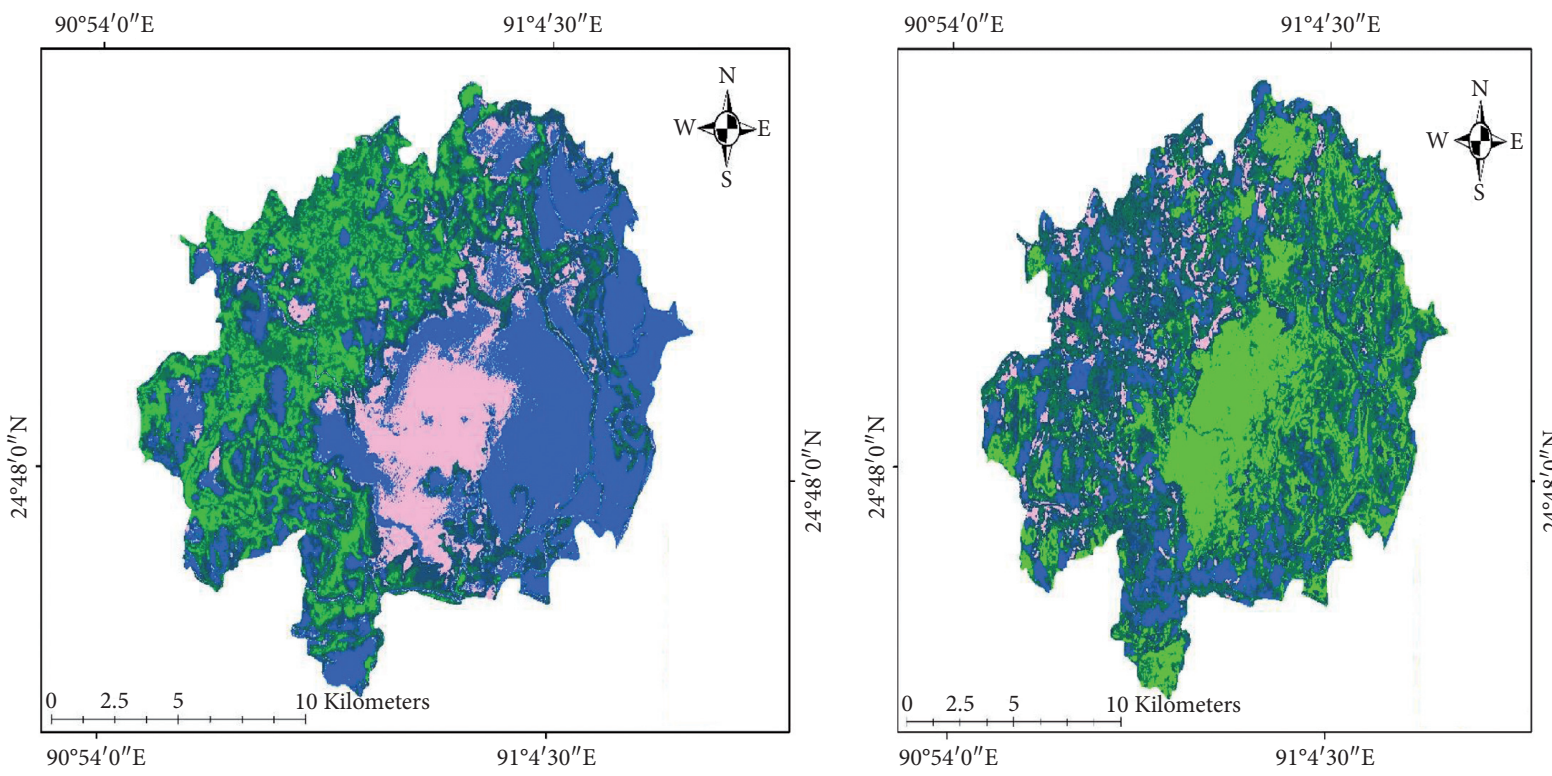

\section{LULC Class \\ $\square$ Agriculture \\ $\square$ Dry fallow \\ Tree \\ $\square$ Water \\ Wet fallow}

(a)

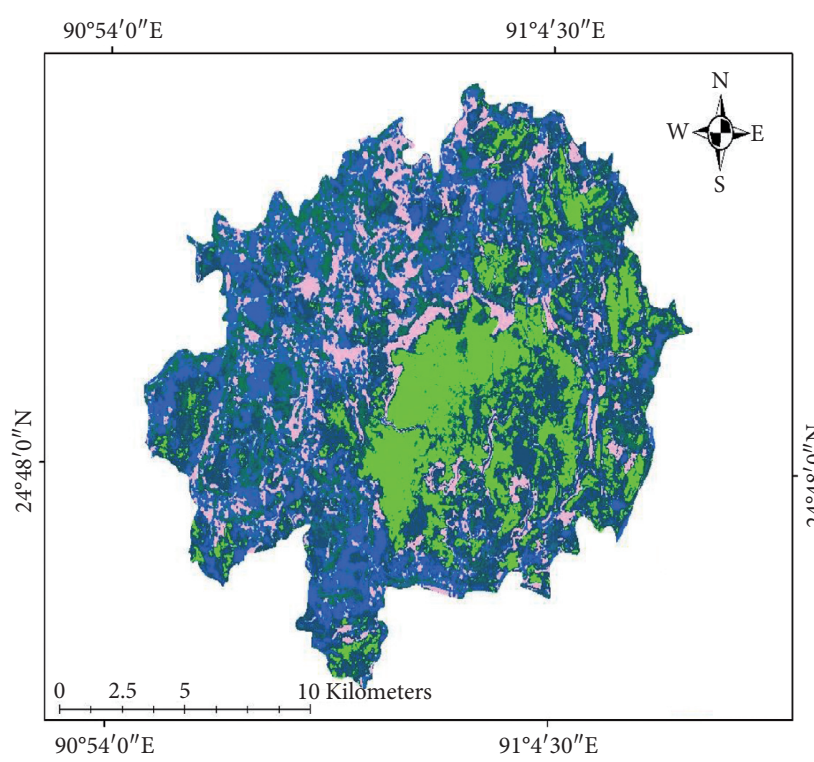
LULC Class
$\square$ Agriculture
$\square$ Dry fallow
Tree
Water
Wet fallow

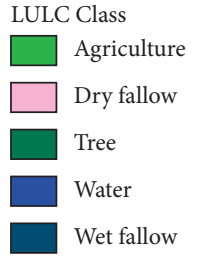

(b)

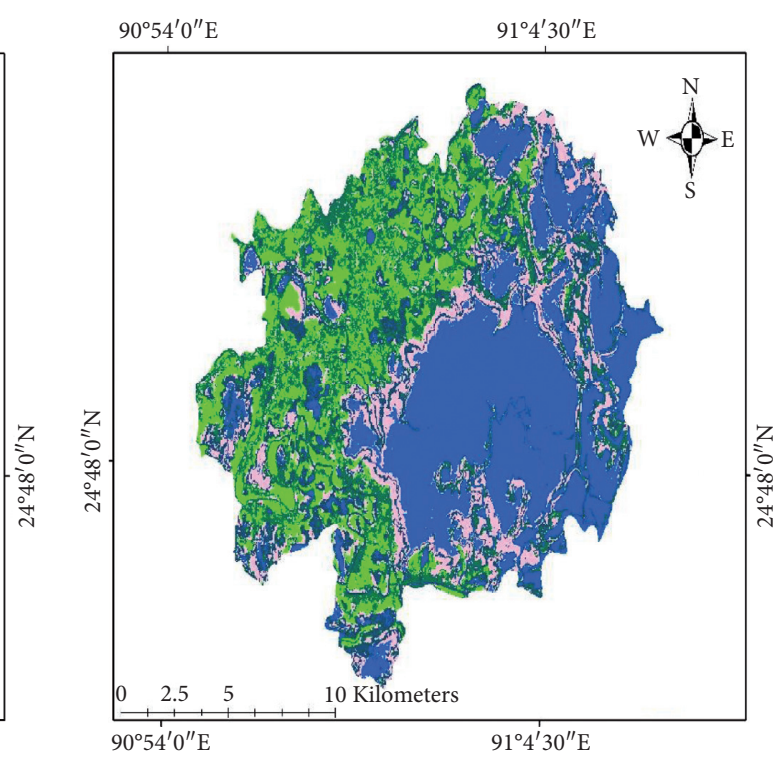
LULC Class

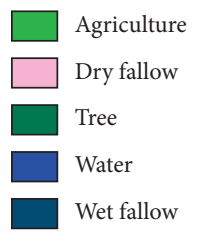

FIgUre 2: Continued. 


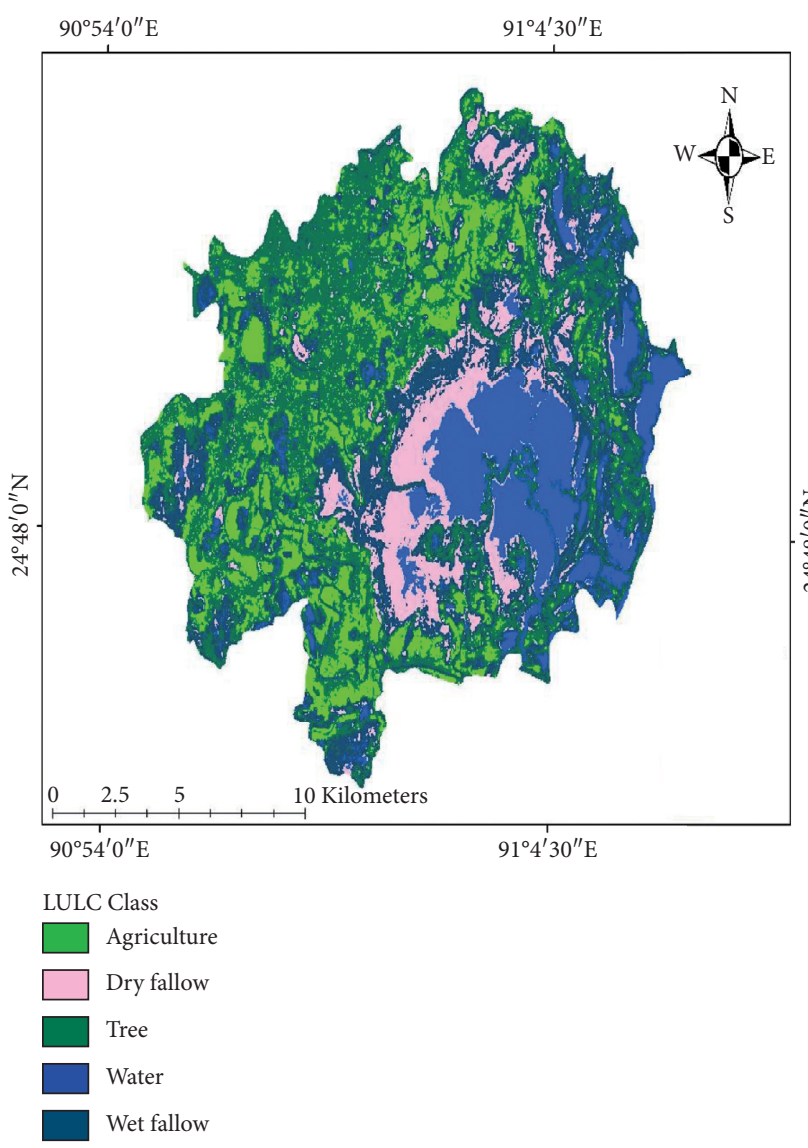

(e)

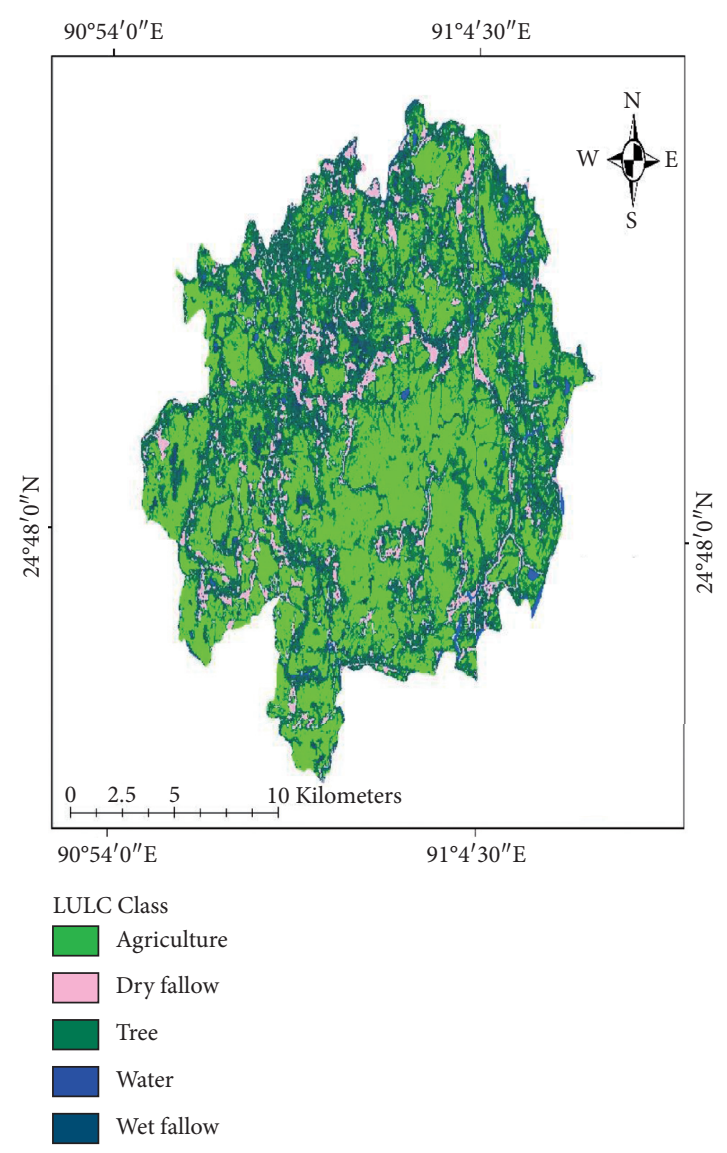

(f)

Figure 2: Changes of land use and land cover (LULC) from 2000 to 2020 in wetland based ecosystem of Mohanganj Upazila. (a) November, 2000, (b) February, 2000, (c) February, 2010, (d) November, 2010, (e) November, 2018, and (f) March, 2020.

(March), respectively. Tree area was changed 27.2 to $119.7 \%$ from 2000 to 2020 (Figures 2(a)-2(f) and Table 2). The estimated water body was $7696.71,5007.42,3137.04$, 2627.64, 4597.92, and 195.21 ha in 2000 (February), 2010 (February), 2020 (March), 2000 (November), 2010 (November), and 2018 (December), respectively. The water body was varied from 35 to $95.7 \%$ during the year 2000 to 2020 (Figures 2(a)-2(f) and Table 2). The dry area was covered with 1162.8 to 3643.2 ha from 2000 to 2020 . The change in the dry area was 7 to $165 \%$ from 2000 to 2020 (Figures 2(a)2(f) and Table 2). The total wet fellow was 2115.2 to 8991.9 ha recorded in 2000 to 2020. In this time, changes of wet fellow were 15.5 to $76.5 \%$ (Figures 2(a)-2(f) and Table 2).

3.3. Least Concern (LC), Vulnerable (VU), and Endangered (EN) Species. Among the 19 fish species studied from 2015 to 2019, 6 fish species (Wallago attu, Ompok pabda, Channa punctate, Chitala chitala, Salmostoma phulo, and Corica soborna) were found VU. However, chital (Ch. chitala) was found VU since rainy season, 2015. Among these fish species, 4 species (W. attu, O. pabda, C. punctate, and Ch. chitala) were EN category in winter, 2019. A total of 13 fish species were recorded as LC from 2015 to 2019 (Table 3). The percentage of LC fish species was reduced though from 2015 to 2019. In dry season 2019 , about $21 \%$ of fish species were found EN with 21\% VU and 58\% LC category. Meanwhile, none of the fish species were recorded EN before the dry season, 2019 (Figures 5(a)-5(c)).

Among the 4 aquatic plant species, both common water hyacinth (Eichhornia crassipes) and water cabbage/water lettuce (Pistia stratiotes) were recorded as LC from the rainy season, 2015, to the winter season, 2019. However, 2 aquatic plant species, red and blue water lily (Nymphaea nouchali) and white lotus or sacred lotus (Nymphaea lotus), were categorized as LC in the rainy season, 2015, but they were changed to $\mathrm{VU}$ in the winter season, 2015 until the rainy season, 2019, which again moved to EN category in dry season 2019 (Table 4). The percentage of aquatic plant species under LC was $100 \%$ in the rainy season, 2015 , but $50 \%$ of them were shifted to VU category during the rainy season, 2019. Meanwhile, during the winter season, 2019, all the VU plant species were changed to EN (Figures 6(a)-6(c)).

In the case of bird species, only two species such as Indian pond heron (Ardeola grayii) and common kingfisher (Alcedo atthis) were categorized as LC in the rainy season, 2015. However, within a short period Ar. Grayii was changed to EN category and Alcedo atthis was moved to VU category during the winter season, 2015, to the rainy season, 2019. Both wild duck (Anas platyrhynchos) and purple swamphen 


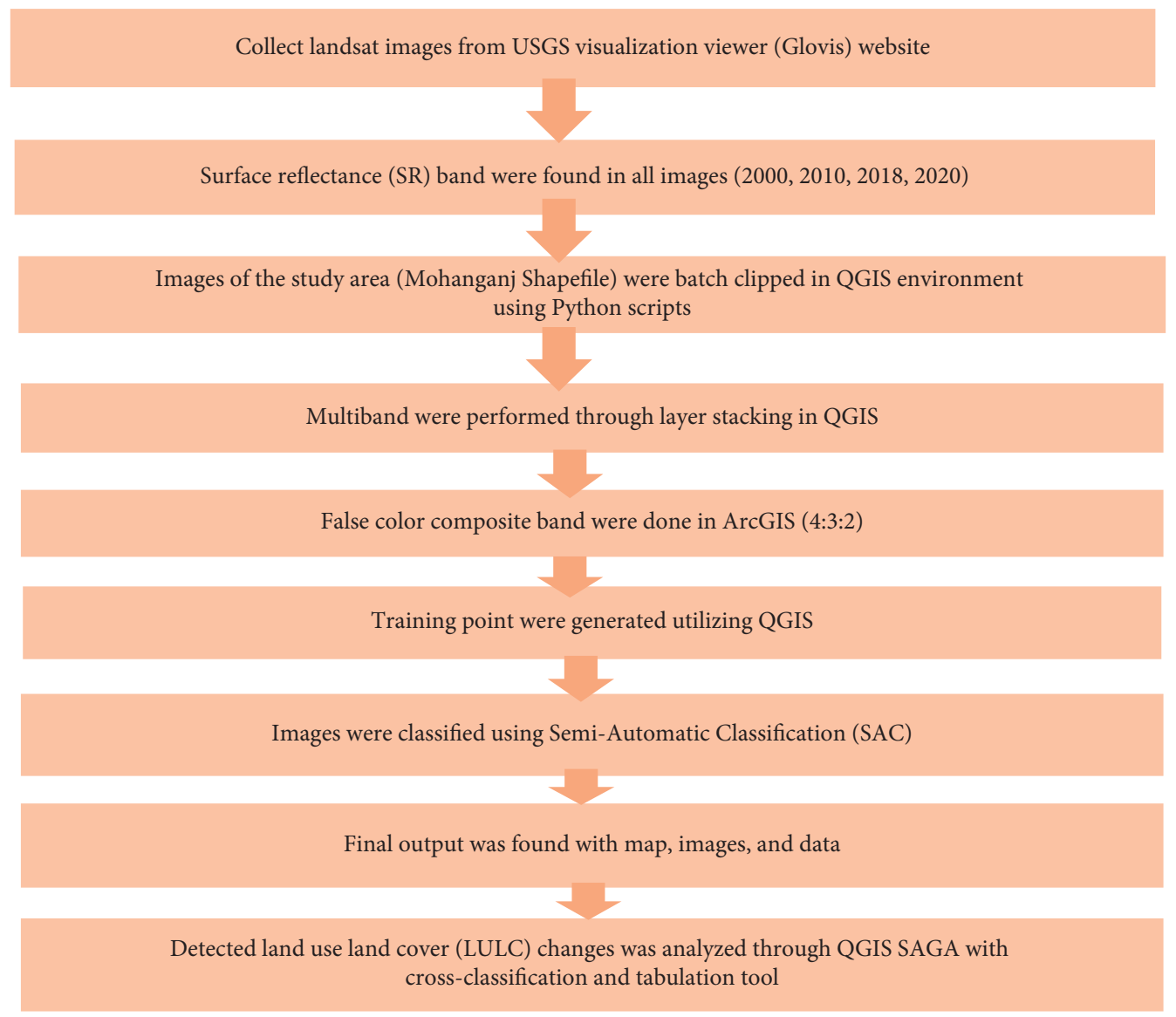

FIGURE 3: Flow chart highlights the procedure of land use and land cover (LULC) changes at wetland based ecosystems of Mohanganj Upazila.

Table 1: Properties of different wetland ecosystems at Mohanganj Upazila.

\begin{tabular}{|c|c|c|c|c|c|c|c|c|c|c|}
\hline $\begin{array}{l}\text { Sl. } \\
\text { number }\end{array}$ & $\begin{array}{c}\text { Name of } \\
\text { wetland }\end{array}$ & $\begin{array}{c}\text { Average } \\
\text { area of } \\
\text { water body } \\
\text { during the } \\
\text { rainy } \\
\text { season } \\
\text { (hectare) }\end{array}$ & $\begin{array}{c}\text { Average } \\
\text { area of } \\
\text { water body } \\
\text { during the } \\
\text { winter } \\
\text { season } \\
\text { (hectare) }\end{array}$ & $\begin{array}{l}\% \text { Water } \\
\text { body } \\
\text { reduced in } \\
\text { winter } \\
\text { season }\end{array}$ & $\begin{array}{l}\text { Source } \\
\text { of water }\end{array}$ & $\begin{array}{c}\text { Water } \\
\text { life }\end{array}$ & $\begin{array}{l}\text { Topography } \\
\text { of } \\
\text { surrounding } \\
\text { area }\end{array}$ & $\begin{array}{l}\text { Major } \\
\text { crops }\end{array}$ & $\begin{array}{l}\text { Type of } \\
\text { wetland }\end{array}$ & $\begin{array}{l}\text { Causes for the } \\
\text { reduction of water } \\
\text { body during the } \\
\text { winter season }\end{array}$ \\
\hline 1 & Nagadura & 26 & 6 & 23 & Rainfall & Medium & Flat & Rice & $\mathrm{Na}$ & \\
\hline 2 & Dingaputa & 46539 & 6272 & 13 & Rainfall & High & Flat & Rice & Natural & $\mathrm{Emb}$ \\
\hline 3 & Chadra & 90 & 26 & 29 & Rainfall & Medium & Medium high & Rice & Natural & irrigation, low \\
\hline 4 & Sonapeti & 65 & 22 & 34 & Rainfall & Medium & Medium high & Rice & Natural & rainfall, and water \\
\hline 5 & Aizda & 59 & 6 & 10 & Rainfall & Low & Medium high & Rice & Natural & transfer into \\
\hline 6 & Firail & 63 & 18 & 29 & Rainfall & Medium & Medium high & Rice & Natural & another area for \\
\hline 7 & Nader & 105 & 19 & 18 & Rainfall & Medium & Medium high & Rice & Natural & sustainable rice \\
\hline 8 & Sonarthal & 65 & 22 & 34 & Rainfall & Medium & Medium high & Rice & Natural & farming \\
\hline 9 & Khalaura & 66 & 18 & 27 & Rainfall & Low & Medium high & Rice & Natural & \\
\hline
\end{tabular}

(Porphyrio porphyria) were grouped into VU during the rainy season, 2015, until winter season, 2019. Meanwhile, Black-headed gull (Larus ridibundus) and sukun (Gyps bengalensis) were categorized into $\mathrm{EN}$ from rainy season, 2015, till winter season, 2019. All the observed bird species (hundred percent) were found EN in the dry season, 2019 (Table 5; Figures 7(a)-7(c)).
3.4. Identification of Highly Endangered Species. We identified several species (fish, aquatic plants, and birds) more endangered (EN) than predicted by chance (Table 6). Among the bird species, purple swamphen (Po. porphyria) and black-headed gull ( $L$. ridibundus) were highly endangered $(p \leq 0.001)$ than other bird species. Among the fish species, $W$. attu and $C$. chitala both were highly endangered 


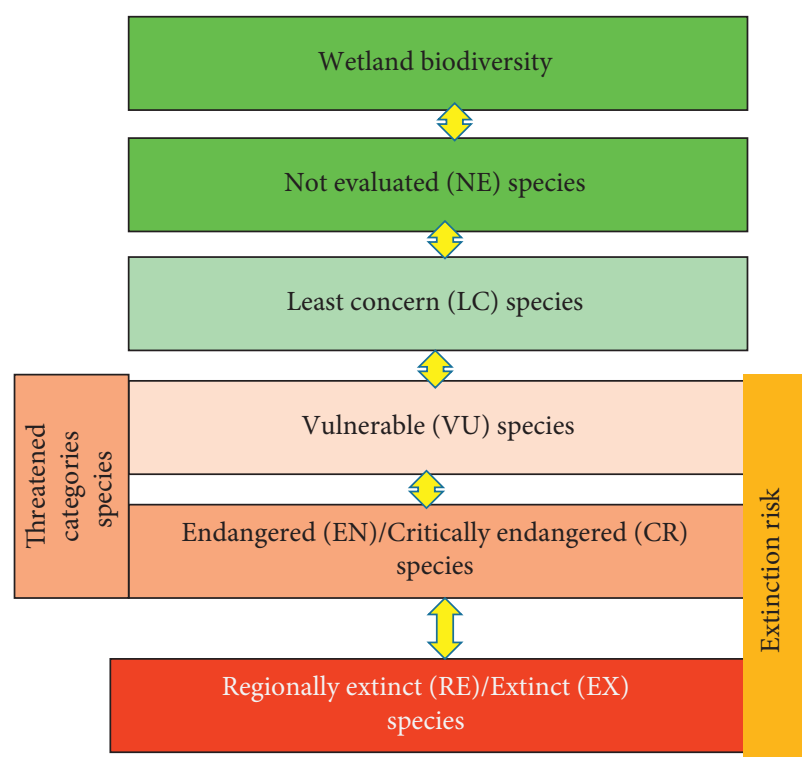

FIGURE 4: Flow chart of red list categories according to IUCN.

$(p \leq 0.01)$ compared to the rest of the species. The aquatic plant species red and blue water lily ( $N y$. nouchali) was highly endangered $(p \leq 0.01)$ (Table 6$)$.

3.5. Major Environmental Threats. Based on public perception, major environmental threats in the study area were identified as unplanned fishing, deforestation, logging, random development of residential/commercial areas, invasive alien species, hunting/trapping, climate change, dam/ embankments, human disturbance, waste disposal without treatment, transport/service corridors, application of nonrecommended doses of pesticides, unplanned irrigation during the dry season, chemical fertilization, and sustainable rice cultivation (Figure 8).

\section{Discussion}

Wetland is a good resource for biological diversity. Wetland supports aquatic birds, fishes, amphibians, reptiles, and plant species during important life stages by providing roosting, nesting, and feeding habitat as well as a sanctuary during extreme weather conditions [25].

In this study, the percentages of least concern (LC) fish species declined in 2019 as compared to 2015 and 2017. However, the percentage of both vulnerable (VU) and endangered (EN) fish species was increased in 2019. Interestingly, the vulnerability of fish species was increased in winter as compared to the summer season (Figures 5(a)5(c)). Our study corroborates the finding of Hakaluki wetland in Bangladesh [26] where they found $14.46 \%$ and $21.69 \%$ fish species were recorded as VU and EN, respectively. According to the red list of IUCN, globally about $1 \%$ of fish species was critically endangered (CN), 6\% of fish species were EN, $22 \%$ of fish species were VU, $30 \%$ of fish species were at Lower Risk Near Threatened (LRNT), and $30 \%$ fish species as lower risk least concerned (LRLC) [27].
Regionally, in the wetland of East Kolkata, about $59 \%$ of fish species were recorded as near threatened (NT) to EN [27].

Geographically, Mohanganj is occupied with a large river network and few big lakes, but excessive irrigation, low rainfall, and global warming reduce the water bodies of the wetland ecosystem (Table 1). As a result, only $57 \%$ of fish species were found to be LC, but $21.05 \%$ and $21.05 \%$ of fish species were recorded as $\mathrm{VU}$ and $\mathrm{EN}$, respectively, during winter in 2019 (Figures 5(a)-5(c)). The fish species Wallago attu, Ompok pabda, Channa punctate, and Chitala chitala were recorded as an EN, but the family Carcharhinidae (e.g., Wallago attu) was found to be extremely EN (Table 6). Similar to our results, Chowdhury et al. [28] categorized 24, $19,24,7$, and 3 fish species as available, moderately available, rarely available, very rarely available, and extinct, respectively among the 77 fish species under 25 families. Another study in Bangladesh reported that the highest number of fish species was observed from October to December; however, the lowest number of fish species was observed from March to April [29]. According to Islam et al. [29], out of 54 threatened red-listed fish species by IUCN in Bangladesh, only 30 species were highly visible for the last 20 years, but, currently, 23 species were categorized as only visible. Subsequently, a large number of fish species were added to the red list by the IUCN Red List of Bangladesh [30].

Aquatic plant species provide food and shelter for the survival of wetland fish species. In this study, both VU and EN aquatic plant species have been increased in 2019 as compared to 2015 and 2017, while $100 \%$ of aquatic plant species were found as LC during the rainy season in 2015. Meanwhile, over time LC species decreased and 50\% of aquatic species were moved down to the EN category during winter in 2019. Also, the family Nymphaeaceae (species: Nymphaea nouchali) was recorded as highly EN species (Tables 4 and 6; Figures 6(a)-6(c)). In this study, it is proved that the diversity of wetland plant species has been declined in 2019 as compared to 2015. The decline of water bodies may be the principal reason for the decreasing trend of aquatic plant species in Mohanganj. Similar to these study areas, global water pollution is one of the major reasons for biodiversity losses in wetland ecosystems [31]. According to the public perception, the water bodies in the study area at Mohanganj Upazila were polluted due to excessive use of pesticides (Figure 8 ). Therefore, the loss of biodiversity in the wetlands of the study area in 2019 may happen due to water pollution by pesticides. In Asia, the number of wetland species, such as great knot (Calidris tenuirostris) and far eastern curlew (Numenius madagascariensis), was reduced rapidly due to water pollution [32].

All the bird species were recorded EN during winter in 2019 (Figures 7(a)-7(c) and Table 5) and the highly EN families were Rallidae (Porphyrio porphyria) and Laridae (Larus ridibundus) (Table 6). According to the red list of IUCN in Bangladesh [33], 38 bird species were near threatened (NT) and 78 species were considered threatened or near threatened. Among these bird species, dwarf kingfisher (Ceyx erithaca), bristled grassbird (Chaetornis striata), eagle (Haliaeetus leucoryphus), Indian spotted eagle (Aquila hastate), and masked finfoot (Heliopais personata) 


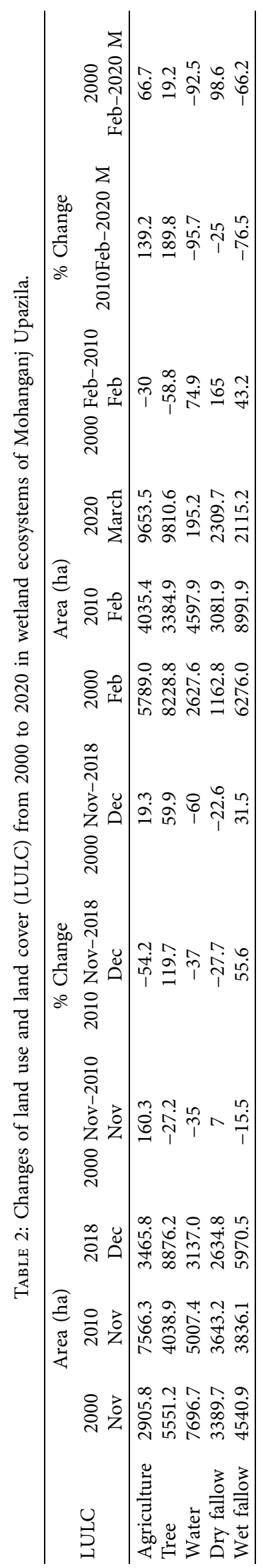


TABLE 3: Seasonal variation of fish species at different wetland ecosystems.

\begin{tabular}{|c|c|c|c|c|c|c|c|c|c|}
\hline \multirow[b]{2}{*}{$\begin{array}{l}\text { Name } \\
\text { of } \\
\text { species }\end{array}$} & \multirow[b]{2}{*}{$\begin{array}{l}\text { Local } \\
\text { name }\end{array}$} & \multirow[b]{2}{*}{ English name } & \multirow[b]{2}{*}{ Scientific name } & \multicolumn{2}{|c|}{ Status of species, 2015} & \multicolumn{2}{|c|}{ Status of species, 2017} & \multicolumn{2}{|c|}{ Status of species, 2019} \\
\hline & & & & $\begin{array}{c}\text { Rainy } \\
\text { season } \\
\text { (July } \\
2015 \text { ) }\end{array}$ & $\begin{array}{l}\text { Winter/dry } \\
\text { season } \\
\text { (December } \\
\text { 2015) }\end{array}$ & $\begin{array}{c}\text { Rainy } \\
\text { season } \\
\text { (July } \\
2017 \text { ) }\end{array}$ & $\begin{array}{c}\text { Winter/dry } \\
\text { season } \\
\text { (December } \\
\text { 2017) }\end{array}$ & $\begin{array}{c}\text { Rainy } \\
\text { season } \\
\text { (July } \\
2019 \text { ) }\end{array}$ & $\begin{array}{c}\text { Winter/dry } \\
\text { season } \\
\text { (December } \\
\text { 2019) }\end{array}$ \\
\hline \multirow{19}{*}{ Fish } & Chikra & $\begin{array}{l}\text { Barred spiny } \\
\text { eel }\end{array}$ & $\begin{array}{l}\text { Macrognathus } \\
\text { pancalus }\end{array}$ & LC & $L C$ & $\mathrm{LC}$ & $L C$ & $\mathrm{LC}$ & $L C$ \\
\hline & Puti & Puntio barb & Puntius puntio & $\mathrm{LC}$ & $L C$ & $\mathrm{LC}$ & $L C$ & LC & $L C$ \\
\hline & Shing & $\begin{array}{l}\text { Stinging } \\
\text { catfish }\end{array}$ & $\begin{array}{l}\text { Heteropneustes } \\
\text { fossilis }\end{array}$ & $\mathrm{LC}$ & $L C$ & LC & $L C$ & $\mathrm{LC}$ & $L C$ \\
\hline & Magur & $\begin{array}{l}\text { Walking } \\
\text { catfish }\end{array}$ & Clarias batrachus & LC & $L C$ & $\mathrm{LC}$ & $L C$ & $\mathrm{LC}$ & $L C$ \\
\hline & Boal & $\begin{array}{l}\text { Freshwater } \\
\text { shark }\end{array}$ & Wallago attu & $\mathrm{LC}$ & $V U$ & VU & $V U$ & VU & $E N$ \\
\hline & Rui & Rohu & Labeo rohita & $\mathrm{LC}$ & $L C$ & $\mathrm{LC}$ & $L C$ & $\mathrm{LC}$ & $L C$ \\
\hline & Koi & $\begin{array}{l}\text { Climbing } \\
\text { perch }\end{array}$ & Anabas testudineus & $\mathrm{LC}$ & $L C$ & $\mathrm{LC}$ & $L C$ & $\mathrm{LC}$ & $V U$ \\
\hline & Pabda & $\begin{array}{l}\text { Pabdah } \\
\text { catfish }\end{array}$ & Ompok pabda & $\mathrm{LC}$ & $V U$ & VU & $V U$ & VU & $E N$ \\
\hline & Tengra & $\begin{array}{l}\text { Striped dwarf } \\
\text { catfish }\end{array}$ & Mystus vittatus & $\mathrm{LC}$ & $L C$ & $\mathrm{LC}$ & $L C$ & $\mathrm{LC}$ & $L C$ \\
\hline & Bailla & Tank goby & Glossogobius giuris & $\mathrm{LC}$ & $L C$ & $\mathrm{LC}$ & $L C$ & LC & $V U$ \\
\hline & Gutum & Guntea loach & $\begin{array}{c}\text { Lepidocephalichthys } \\
\text { guntea }\end{array}$ & $\mathrm{LC}$ & $L C$ & LC & $L C$ & LC & $L C$ \\
\hline & Chingri & Shrimp & $\begin{array}{l}\text { Fenneropenaeus } \\
\text { indicus }\end{array}$ & $\mathrm{LC}$ & $L C$ & LC & $L C$ & $\mathrm{LC}$ & $L C$ \\
\hline & Katal & Catla & Gibelion catla & $\mathrm{LC}$ & $L C$ & $\mathrm{LC}$ & $L C$ & LC & $L C$ \\
\hline & Taki & $\begin{array}{l}\text { Spotted } \\
\text { snakehead }\end{array}$ & Channa punctate & $\mathrm{LC}$ & $V U$ & VU & $V U$ & VU & $E N$ \\
\hline & Chital & $\begin{array}{l}\text { Clown } \\
\text { knifefish }\end{array}$ & Chitala chitala & VU & $V U$ & VU & $V U$ & VU & $E N$ \\
\hline & Chada & $\begin{array}{c}\text { Elongate } \\
\text { glass perchlet }\end{array}$ & Chanda nama & $\mathrm{LC}$ & $L C$ & $\mathrm{LC}$ & $L C$ & $\mathrm{LC}$ & $L C$ \\
\hline & Chela & $\begin{array}{c}\text { Finescale } \\
\text { razorbelly } \\
\text { minnow }\end{array}$ & Salmostoma phulo & $\mathrm{LC}$ & $V U$ & VU & $V U$ & VU & $V U$ \\
\hline & Mola & Mola carplet & $\begin{array}{c}\text { Amblypharyngodon } \\
\text { mola }\end{array}$ & $\mathrm{LC}$ & $L C$ & $\mathrm{LC}$ & $L C$ & $\mathrm{LC}$ & $L C$ \\
\hline & Kachki & $\begin{array}{c}\text { Ganges river } \\
\text { sprat }\end{array}$ & Corica soborna & $\mathrm{LC}$ & $V U$ & VU & $V U$ & VU & $V U$ \\
\hline
\end{tabular}

Note: VU, vulnerable (any species that is likely to become endangered within the foreseeable future); EN, endangered (any species that is at risk of extinction); $L C$, least concern (a species that has been categorized by the International Union for Conservation of Nature [IUCN] as evaluated as not being a focus of species conservation).

were globally identified as threatened. In Bangladesh, whiterumped vulture (G. bengalensis) and slender-billed vulture (Gyps tenuirostris) were extremely critical [33]. Also, 17 and 12 bird species were identified as VU and EN category, respectively, in Bangladesh [33]. Lesser adjutant (Leptoptilos javanicus), great hornbill (Buceros bicornis), and grey peacock-pheasant (Polyplectron bicalcaratum) were identified highly VU in Bangladesh [33]. In our study, we found that G. bengalensis was EN species in the wetland ecosystem of Mohanganj (Tables 5 and 6).

However, the land use and land cover (LULC) with crops, trees, waterbody, and dry and wet fallows is significantly important for the diversity of species in the wetland ecosystem. The change of biological resources in an ecosystem depends on the LULC of a particular territory. The LULC of Mohanganj Upazilla was changed in the last two decades due to human activities. Likewise, the LULC was changed across the globe. For instance, the water body was declined by $1 \%$ and the forest by $4 \%$ between 1990 and 1998 at Kibasira Swamp in Kilombero Valley of Tanzania [34]. There was a decrease in areas covered by water by $35 \%$ and forest by $9 \%$, whereas C. papyrus L increased by $40 \%$ and cultivated land increased by 8\% between 1998 and 2011 [34]. The LULC was sharply reduced in Inle Lake, Myanmar, which was 4.2 times higher in 2014 than that of 1989. LULC with forest area has been declined by $92 \mathrm{~km}^{2}$ (8.56\%) for the last 25 years in the Inle wetland ecosystem [35]. Biodiversity with land use and land cover has been changed at Quirimbas National Park in Northern Mozambique of Africa due to intensive agriculture, human settlements, population growth, illegal exploitation of forest resources, and mining. Literature showed that about $86.95 \%$ of land use and land 


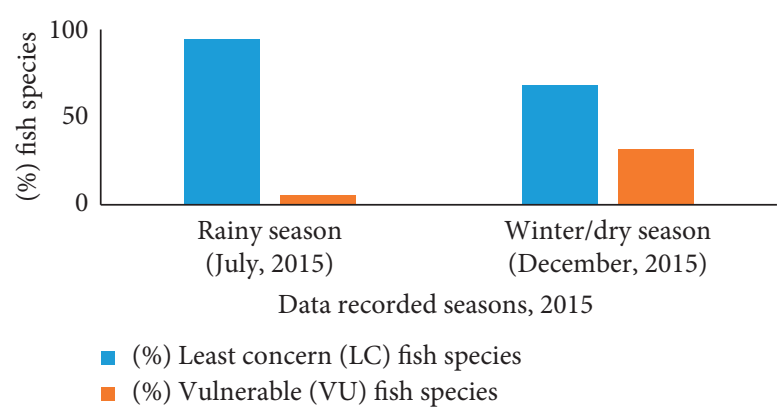

(a)

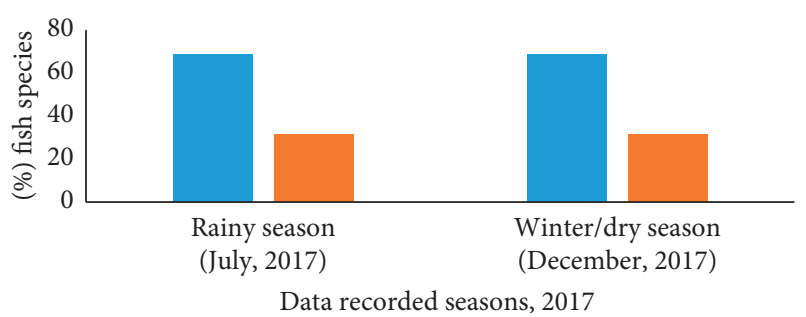

- (\%) Least concern (LC) fish species

- (\%) Vulnerable (VU) fish species

(b)

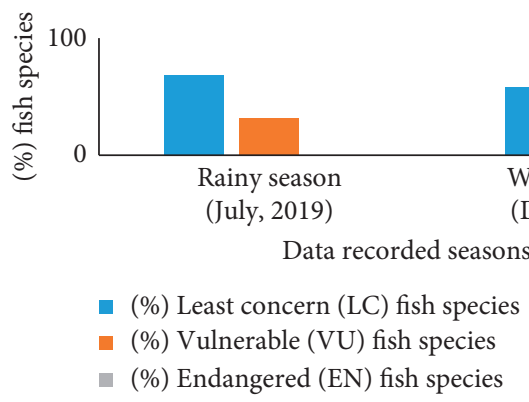

(c)

FIgURE 5: Yearly variation of fish species (a) 2015, (b) 2017, and (c) 2019 at different wetland ecosystems.

TABle 4: Seasonal variation of aquatic plant species at different wetland ecosystems.

\begin{tabular}{|c|c|c|c|c|c|c|c|c|c|}
\hline \multirow[b]{2}{*}{$\begin{array}{l}\text { Name of } \\
\text { species }\end{array}$} & \multirow[b]{2}{*}{ Local name } & \multirow[b]{2}{*}{$\begin{array}{l}\text { English } \\
\text { name }\end{array}$} & \multirow[b]{2}{*}{$\begin{array}{l}\text { Scientific } \\
\text { name }\end{array}$} & \multicolumn{2}{|c|}{ Status of species, 2015} & \multicolumn{2}{|c|}{ Status of species, 2017} & \multicolumn{2}{|c|}{ Status of species, 2019} \\
\hline & & & & $\begin{array}{c}\text { Rainy } \\
\text { season } \\
\text { (July 2015) } \\
\end{array}$ & $\begin{array}{l}\text { Winter/dry season } \\
\text { (December 2015) }\end{array}$ & $\begin{array}{c}\text { Rainy } \\
\text { season } \\
\text { (July 2017) }\end{array}$ & $\begin{array}{l}\text { Winter/dry season } \\
\text { (December 2017) }\end{array}$ & $\begin{array}{c}\text { Rainy } \\
\text { season } \\
\text { (July 2019) } \\
\end{array}$ & $\begin{array}{c}\text { Winter/dry } \\
\text { season } \\
\text { (December 2019) }\end{array}$ \\
\hline \multirow{4}{*}{$\begin{array}{l}\text { Aquatic } \\
\text { plant }\end{array}$} & Kachuripana & $\begin{array}{l}\text { Common } \\
\text { water } \\
\text { hyacinth }\end{array}$ & $\begin{array}{l}\text { Eichhornia } \\
\text { crassipes }\end{array}$ & LC & $L C$ & $\mathrm{LC}$ & $L C$ & $\mathrm{LC}$ & $L C$ \\
\hline & Topapana & $\begin{array}{l}\text { Water } \\
\text { cabbage/ } \\
\text { water } \\
\text { lettuce }\end{array}$ & $\begin{array}{c}\text { Pistia } \\
\text { stratiotes }\end{array}$ & LC & $L C$ & $\mathrm{LC}$ & $L C$ & $\mathrm{LC}$ & $L C$ \\
\hline & Shapla & $\begin{array}{c}\text { Red and } \\
\text { blue water } \\
\text { lily }\end{array}$ & $\begin{array}{c}\text { Nymphaea } \\
\text { nouchali }\end{array}$ & LC & $V U$ & VU & $V U$ & VU & $E N$ \\
\hline & Padma & $\begin{array}{c}\text { White lotus } \\
\text { or sacred } \\
\text { lotus }\end{array}$ & $\begin{array}{c}\text { Nymphaea } \\
\text { lotus }\end{array}$ & LC & $V U$ & VU & $V U$ & VU & $E N$ \\
\hline
\end{tabular}

Note: VU, vulnerable, (any species that is likely to become endangered within the foreseeable future); EN, endangered (any species that is at risk of extinction); LC, least concern (a species that has been categorized by the International Union for Conservation of Nature [IUCN] as evaluated as not being a focus of species conservation).

cover has been changed for 38 years. Total land area was decreased by about $301,761.7$ ha, corresponding to $41.67 \%$ of the total coverage land [36]. It is estimated that almost 500 million hectares of wetlands are practically degraded in Africa. In those areas, $14 \%$ of the land degradation is a result of vegetation removal, $13 \%$ overexploitation, $49.5 \%$ overgrazing, and $24 \%$ agricultural practices [37]. Similar to world statistics, the LULC at Mohanganj Upazila with crops, trees, water bodies, and other natural resources has been reduced significantly in the last 20 years (Figures 2(a)-2(f) and Table 2). The main causes involved with LULC changes are anthropogenic factors, such as fires, territory fragmentation, intensification of agriculture, livestock, buildings, infrastructure, deforestation, urbanization, mining industry, and natural disasters [38].

In our study, the main reasons for LULC changes were unplanned fishing, deforestation, logging, random development of residential/commercial areas, invasive alien species, hunting/trapping, climate change, dam/embankments, human disturbance, waste disposal without treatment, transport/service corridors, application of nonrecommended doses of pesticides, irrigation, fertilization, 


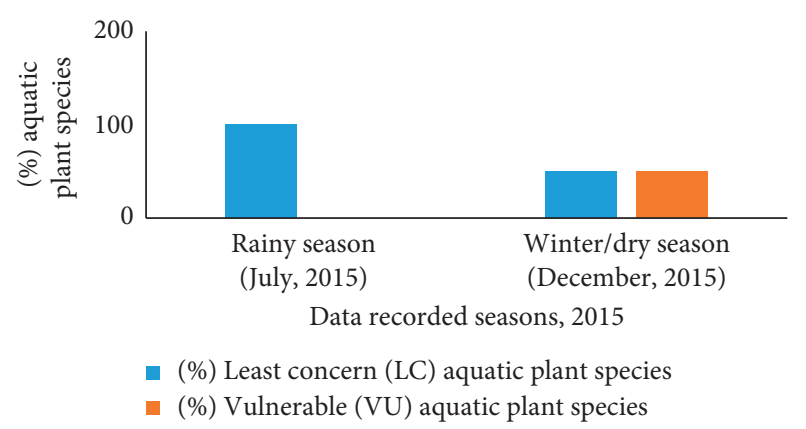

(a)

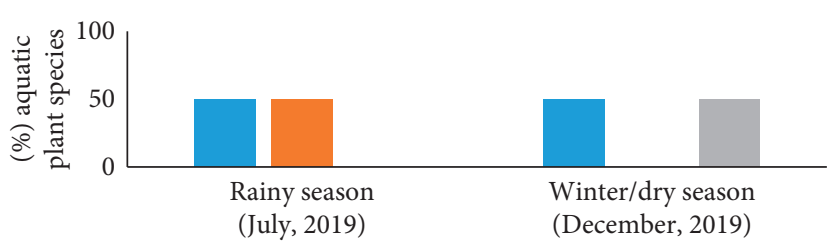

Data recorded seasons, 2019

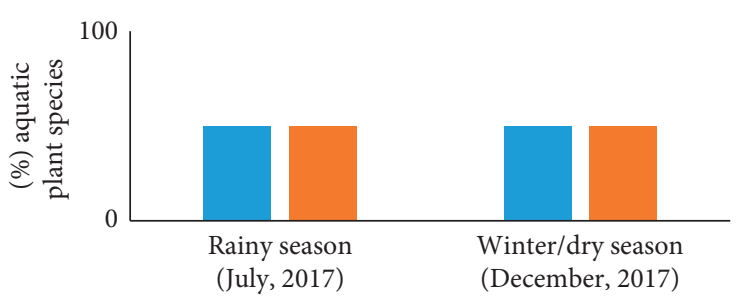

Data recorded seasons 2017

- (\%) Least concern (LC) aquatic plant species

- (\%) Vulnerable (VU) aquatic plant species

(b)

(\%) Least concern (LC) aquatic plant species
(\%) Vulnerable (VU) aquatic plant species
(\%) Endangered (EN) aquatic plant species

(c)

FIGURE 6: Yearly variation of aquatic plant species (a) 2015, (b) 2017, and (c) 2019 at different wetland ecosystems.

TABLE 5: Seasonal variation of bird's species at different wetland ecosystems.

\begin{tabular}{|c|c|c|c|c|c|c|c|c|c|}
\hline \multirow[b]{2}{*}{$\begin{array}{l}\text { Name } \\
\text { of } \\
\text { species }\end{array}$} & \multirow[b]{2}{*}{$\begin{array}{l}\text { Local } \\
\text { name }\end{array}$} & \multirow[b]{2}{*}{$\begin{array}{l}\text { English } \\
\text { name }\end{array}$} & \multirow[b]{2}{*}{ Scientific name } & \multicolumn{2}{|c|}{ Status of species, 2015} & \multicolumn{2}{|c|}{ Status of species, 2017} & \multicolumn{2}{|c|}{ Status of species, 2019} \\
\hline & & & & $\begin{array}{c}\text { Rainy } \\
\text { season } \\
\text { (July 2015) } \\
\end{array}$ & $\begin{array}{l}\text { Winter/dry season } \\
\text { (December 2015) }\end{array}$ & $\begin{array}{c}\text { Rainy } \\
\text { season } \\
\text { (July 2017) } \\
\end{array}$ & $\begin{array}{l}\text { Winter/dry season } \\
\text { (December 2017) }\end{array}$ & $\begin{array}{c}\text { Rainy } \\
\text { season } \\
\text { (July 2019) } \\
\end{array}$ & $\begin{array}{c}\text { Winter/dry } \\
\text { season } \\
\text { (December 2019) }\end{array}$ \\
\hline \multirow{7}{*}{ Bird } & Bali Hash & Wild duck & $\begin{array}{c}\text { Anas } \\
\text { platyrhynchos }\end{array}$ & VU & $V U$ & VU & $E N$ & $\mathrm{EN}$ & $E N$ \\
\hline & Bog & $\begin{array}{l}\text { Indian } \\
\text { pond } \\
\text { heron }\end{array}$ & Ardeola grayii & LC & $E N$ & EN & $E N$ & EN & $E N$ \\
\hline & Shukun & $\begin{array}{l}\text { Bengal } \\
\text { vulture }\end{array}$ & $\begin{array}{c}\text { Gyps } \\
\text { bengalensis }\end{array}$ & EN & $E N$ & EN & $E N$ & EN & $E N$ \\
\hline & Machranga & $\begin{array}{l}\text { Common } \\
\text { kingfisher }\end{array}$ & Alcedo atthis & $\mathrm{LC}$ & $V U$ & VU & $V U$ & $\mathrm{VU}$ & $E N$ \\
\hline & Pankouri & $\begin{array}{l}\text { Indian } \\
\text { shag }\end{array}$ & $\begin{array}{l}\text { Phalacrocorax } \\
\text { fuscicollis }\end{array}$ & VU & $V U$ & VU & $V U$ & $E N$ & $E N$ \\
\hline & Kalim Bird & $\begin{array}{c}\text { Purple } \\
\text { swamphen }\end{array}$ & $\begin{array}{l}\text { Porphyrio } \\
\text { porphyria }\end{array}$ & VU & $E N$ & $\mathrm{EN}$ & $E N$ & $E N$ & $E N$ \\
\hline & Gangchil & $\begin{array}{c}\text { Black- } \\
\text { headed gull }\end{array}$ & $\begin{array}{l}\text { Larus } \\
\text { ridibundus }\end{array}$ & $\mathrm{EN}$ & $E N$ & $\mathrm{EN}$ & $E N$ & $E N$ & $E N$ \\
\hline
\end{tabular}

Note: VU, vulnerable (any species that is likely to become endangered within the foreseeable future); EN, endangered (any species that is at risk of extinction); LC, least concern (a species that has been categorized by the International Union for Conservation of Nature [IUCN] as evaluated as not being a focus of species conservation).

and sustainable agricultural production (Figure 8). According to the Millennium Ecosystem Assessment [MEA] [21] report, the loss of wetland habitats and land degradation were the consequences of overexploitation, alien invasive species, climate change, and pollution. The consequence of wetland declines resulted in a decline of LC species and the increase of VU and EN fish, bird, and aquatic plant species. In this context, $W$. attu, N. nouchaii, G. bengalensis,
$P$. porphyria, and L. ridibundus were extremely endangered categories due to changes of land use and land cover (Table 5).

According to public perception, the loss of biodiversity in the wetlands is due to the rapid expansion of the sustainable agricultural system. Likewise, the expanded practice of sustainable agricultural systems is responsible for the reduction of biodiversity in the wetlands throughout the 


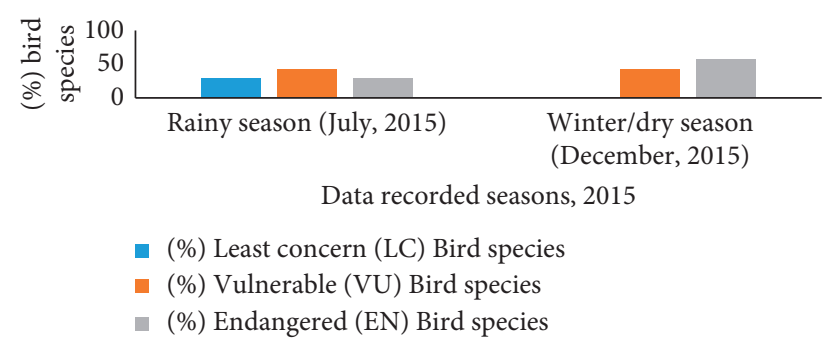

(a)

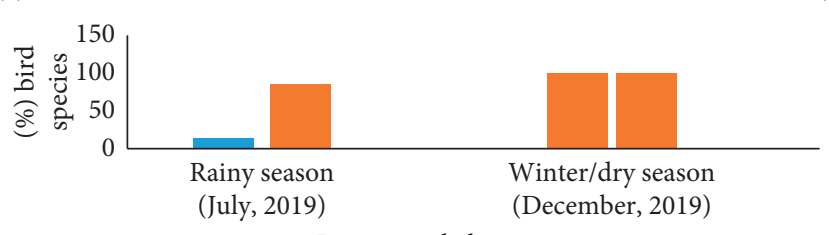

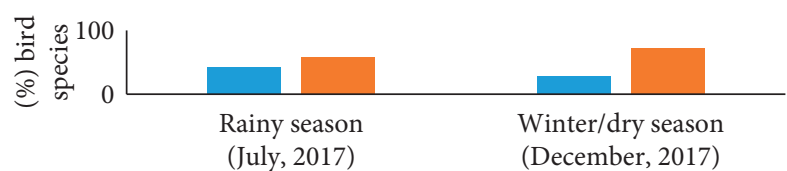

Data recorded seasons, 2017

- (\%) Vulnerable (VU) Bird species

- (\%) Endangered (EN) Bird species

(b)

Data recorded seasons, 2019

- (\%) Vulnerable (VU) Bird species

- (\%) Endangered (EN) Bird species

(c)

FIGURE 7: Yearly variation of bird species (a) 2015, (b) 2017, and (c) 2019 at different wetland ecosystems.

Taвle 6: Endangered fishes, aquatic plants, and bird's species under families at different wetland ecosystems in 2019.

\begin{tabular}{|c|c|c|c|c|c|c|c|}
\hline \multirow[b]{2}{*}{$\begin{array}{l}\text { Category of } \\
\text { species }\end{array}$} & \multirow[b]{2}{*}{ Family } & \multirow[b]{2}{*}{ English name } & \multirow[b]{2}{*}{ Scientific name } & \multicolumn{4}{|c|}{ Endangered families, 2019} \\
\hline & & & & $\begin{array}{l}\text { No. of species } \\
\text { in the family }\end{array}$ & $\begin{array}{c}\text { No. of species } \\
\text { endangered }\end{array}$ & $\begin{array}{l}\text { The proportion of } \\
\text { species endangered }\end{array}$ & $\begin{array}{c}\text { Binomial } \\
\text { probability }\end{array}$ \\
\hline \multirow{4}{*}{ Fishes } & Carcharhinidae & $\begin{array}{c}\text { Freshwater } \\
\text { shark }\end{array}$ & Wallago attu & 4 & 4 & 1.00 & $0.00144^{* *}$ \\
\hline & Siluridae & Pabdah catfish & Ompok pabda & 3 & 2 & 0.67 & 0.0918 \\
\hline & Channidae & $\begin{array}{c}\text { Spotted } \\
\text { snakehead }\end{array}$ & Channa punctate & 6 & 2 & 0.33 & 0.239 \\
\hline & Notopteridae & $\begin{array}{l}\text { Clown } \\
\text { knifefish }\end{array}$ & Chitala chitala & 4 & 3 & 0.75 & $0.023^{*}$ \\
\hline $\begin{array}{l}\text { Aquatic } \\
\text { plants }\end{array}$ & Nymphaeaceae & $\begin{array}{l}\text { Red and blue } \\
\text { water lily }\end{array}$ & $\begin{array}{c}\text { Nymphaea } \\
\text { nouchali }\end{array}$ & 7 & 5 & 0.71 & $0.0038^{* *}$ \\
\hline \multirow{8}{*}{ Birds } & Anatidae & Wild duck & $\begin{array}{c}\text { Anas } \\
\text { platyrhynchos }\end{array}$ & 3 & 2 & 0.67 & 0.091 \\
\hline & Ardeidae & $\begin{array}{l}\text { Indian pond } \\
\text { heron }\end{array}$ & Ardeola grayii & 4 & 1 & 0.25 & 0.4 \\
\hline & Accipitridae & Bengal vulture & Gyps bengalensis & 6 & 5 & 0.83 & $0.0013^{* *}$ \\
\hline & Alcedinidae & $\begin{array}{l}\text { Common } \\
\text { kingfisher }\end{array}$ & Alcedo atthis & 4 & 2 & 0.50 & 0.147 \\
\hline & Phalacrocoracidae & Indian shag & $\begin{array}{l}\text { Phalacrocorax } \\
\text { fuscicollis }\end{array}$ & 3 & 2 & 0.67 & 0.091 \\
\hline & Rallidae & $\begin{array}{c}\text { Purple } \\
\text { swamphen }\end{array}$ & $\begin{array}{l}\text { Porphyrio } \\
\text { porphyria }\end{array}$ & 9 & 7 & 0.78 & $0.00025^{* * *}$ \\
\hline & Laridae & $\begin{array}{l}\text { Black headed } \\
\text { gull }\end{array}$ & Larus ridibundus & 7 & 6 & 0.86 & $0.0003^{* * *}$ \\
\hline & & Total & & & 41 & 8.02 & \\
\hline
\end{tabular}

Note: Even probability $P=$ total proportion of species endangered/total number of species endangered $=8.02 / 41=0.1955$. Binomial probability of each endangered species was calculated using statistical software Minitab. ${ }^{* * *}$ indicates significant difference at $p \leq 0.001$ level of significance, ${ }^{* *}$ indicates significant difference at $p \leq 0.01$ level of significance, and ${ }^{*}$ indicate significant difference at $p \leq 0.05$ level of significance.

globe [39]. Intensification of agriculture results introduces new pests and pathogens in different cropping patterns [40] which needs an indiscriminate use of pesticides to control their resurgence. Thus, the wetland ecosystem is disrupted [41]. In the UK, agricultural intensification caused a massive reduction of biodiversity; two-thirds of 333 plant and animal species have been lost [42]. Sixty percent of the 1,146 freshwater taxa were assessed as threatened, and 228 species were reported to be extinct in wetlands since the last century in the world because of pollution $[43,44]$.

Wetlands are not only required for the conservation of biodiversity but also essential for food, fuel, water, climate 


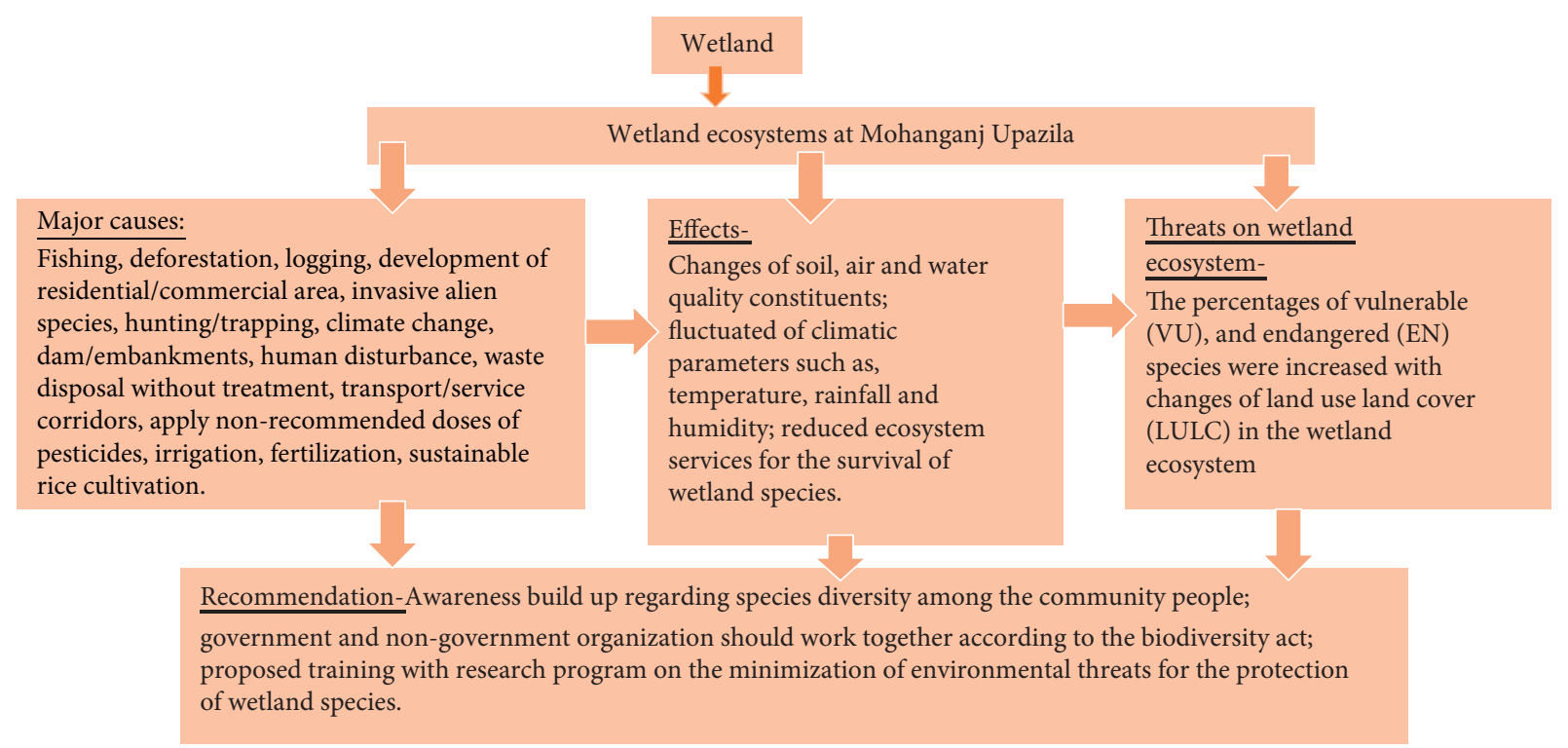

FIGURE 8: Effects of environmental threats on species diversity at wetland ecosystems of Mohanganj Upazila.

regulation, aesthetic, spiritual, recreational activities, soil nutrient cycling, carbon sequestration, and sustainable livelihood for the human being [45]. Still, several aquatic fish and plant species such as M. pancalus, $P$. puntio, $H$. fossilis, C. batrachus, L. rohita, M. vittatus, G. giuris, L. guntea, F. indicus, G. catla, C. nama, A. mola, E. crassipes, and $P$. stratiotes are highly visible due to their high adaptation capacity with changing environment in this wetland ecosystem (Tables 3 and 4 ). As a result, community people are getting benefits from the wetland ecosystem for their sustainable livelihood. Therefore, the protection of wetland biodiversity is necessary for the mitigation of climate change and a sustainable environment. Hence, continuous research and monitoring, awareness building among the wetland community people, and collaborative research and development work between the government and nongovernment organizations are highly recommended for the protection of wetland ecosystems.

\section{Conclusions}

Wetland birds, aquatic plants, and fish species of Mohangonj Upazilla were recorded as VU to EN category between 2015 and 2019. The wetland species belonging to the EN category were considered as an extreme risk due to changes in land use and land cover. The decline of biodiversity was worsened in the dry season. W. attu, N. nouchaii, G. bengalensis, $P$. porphyria, and L. ridibundus were found in extremely endangered categories. If this condition prevails, then many of the wetland species will be extinct from Mohangonj in the next few years. The existing species should be restored for species conservation and environmental sustainability. Hence, awareness with training and research programs on the minimization of environmental threats will be helpful for the protection of wetland species to the development of a sustainable environment among the wetland-based community people.

\section{Data Availability}

All the data are available within the manuscript.

\section{Conflicts of Interest}

The authors declare they do not have conflicts of interest.

\section{Authors' Contributions}

MZA analyzed the data and wrote the manuscript. MABB and MSA discussed the data and provided constructive suggestions. HMA worked with GIS to perform land use and land cover changes (LULC). SRG performed data collection and the statistical analysis. MMH collected data and revised the paper. RA and MR produced the statistical outputs and graphics. All the authors revised and approved the final manuscript.

\section{Acknowledgments}

This work was funded by the Ministry of Science and Technology for carrying out these research activities. The authors are immensely grateful to the Department of Environmental Science, Ministry of Science and Technology, Bangabandhu Sheikh Mujibur Rahman Agricultural University (BSMRAU), Gazipur, Bangladesh, for their funding, logistic, and scholastic supports.

\section{References}

[1] M. Z. Alam, L. Carpenter-Boggs, A. Rahman et al., "Water quality and resident perceptions of declining ecosystem services at Shitalakka wetland in Narayanganj city," Sustainability of Water Quality and Ecology, vol. 9-10, pp. 53-66, 2017 c.

[2] P. Lamsal, K. P. Pant, L. Kumar, and K. Atreya, "Sustainable livelihoods through conservation of wetland resources: a case 
of economic benefits from Ghodaghodi Lake, western Nepal," Ecology and Society, vol. 20, p. 10, 2015.

[3] A. Ossola, A. K. Hahs, and S. J. Livesley, "Habitat complexity influences fine scale hydrological processes and the incidence of stormwater runoff in managed urban ecosystems," Journal of Environmental Management, vol. 159, pp. 1-10, 2015.

[4] S. N. Islam, S. Reinstädtler, and A. Gnauck, "Vulnerability of mangrove forests and wetland ecosystems in the sundarbans natural world heritage site (Bangladesh)," in Threats to Mangrove Forests, pp. 223-243, Springer, Cham, Switzerlnad, 2018.

[5] A. B. M. S. Alam, M. K. Badhon, and M. W. Sarker, Biodiversity of Tanguar Haor: A Ramsar Site of Bangladesh Volume III: Fish, IUCN, International Union for Conservation of Nature, Bangladesh Country Office, Dhaka, Bangladesh, 2015.

[6] M. N. Naser, Wetlands in Bangladesh: Diversity, Resources and People The Independent, Dhaka, Bangladesh, 2020, http:// www.theindependentbd.com/printversion/details/235311.

[7] P. Comer, A. Goodin, K. Tomaino et al., Biodiversity Values of Geographically Isolated Wetlands in the United States, Nature Serve, Arlington, VA, USA, 2005.

[8] M. S. Hossain, G. D. Nani, and M. S. N. Chowdhury, Fisheries Management of Naaf River, Institute of Marine Science and Fisheries, University of Chittagong, University of Chittagong and Center for Good Governance, Chittagong, Bangladesh, 2007.

[9] M. Z. Alam, "Status of biodiversity at wetland ecosystem of Mohangonj Upazila in netrakona district," Advances in Ecology, vol. 2014, Article ID 642450, 8 pages, 2014.

[10] M. Z. Alam, Environmental Threats in Wetland Ecosystems, The Daily Observer, Dhaka, Bangladesh, 2020, https://www. observerbd.com/news.php?id=276068.

[11] M. Mia, M. S. Islam, N. Begum, I. N. Suravi, and S. Ali, "Fishing gears and their effect on fish diversity of Dekar haor in Sunamganj district," Journal of Sylhet Agricultural University, vol. 4, pp. 111-120, 2017.

[12] K. L. Erwin, "Wetlands and global climate change: the role of wetland restoration in a changing world," Wetlands Ecology and Management, vol. 17, no. 1, pp. 71-84, 2009.

[13] J. A. Cherry, "Ecology of wetland ecosystems: water, substrate, and life," Nature Education Knowledge, vol. 3, p. 16, 2011.

[14] I. A. Janssens, A. Freibauer, B. Schlamadinger et al., "The carbon budget of terrestrial ecosystems at country-scale-a European case study," Biogeosciences, vol. 2, no. 1, pp. 15-26, 2005.

[15] W. Chen, B. He, D. Nover et al., "Farm ponds in southern China: challenges and solutions for conserving a neglected wetland ecosystem," The Science of the Total Environment, vol. 659, pp. 1322-1334, 2019.

[16] M. Z. Alam, L. Carpenter-Boggs, S. Mitra et al., "Effect of salinity intrusion on food crops, livestock and fish species at Kalapara coastal belt in Bangladesh," Journal of Food Quality, vol. 2017, Article ID 2045157, 23 pages, 2017.

[17] A. H. Sheikh, A. H. Molla, M. H. Haque, and M. Z. Alam, "Evaluation of water quality and biodiversity of natural freshwater wetlands discharged by industrial effluent," Academia Journal of Environmental Sciences, vol. 5, pp. 52-64, 2017.

[18] W. H. Conner, K. W. McLeod, and J. K. McCarron, "Flooding and salinity effects on growth and survival of four common forested wetland species," Wetlands Ecology and Management, vol. 5, no. 2, pp. 99-109, 1997.

[19] M. Z. Alam, J. Halsey, M. M. Haque, M. Talukdar, M. Moniruzzaman, and A. R. Crump, "Effect of natural disasters and their coping strategies in the kuakata coastal belt of patuakhali Bangladesh," Computational Water, Energy, and Environmental Engineering, vol. 7, no. 4, pp. 161-182, 2018.

[20] C. M. Cheffings and L. Farrell, The Vascular Plant Red Data List for Great Britain No. 7, JNCC, Peterborough, UK, 2005.

[21] MEA (Millennium Ecosystem Assessment), "Ecosystems and human well-being: synthesis," 2005, http://www. millenniumassessment.org.

[22] L. Zhang, B. Wu, K. Yin, X. Li, K. Kia, and L. Zhu, "Impacts of human activities on the evolution of estuarine wetland in the Yangtze Delta from 2000 to 2010," Environmental Earth Sciences, vol. 73, no. 1, pp. 435-447, 2015.

[23] J. Beher, "Pasture characteristics in three different ecotypes at khovd aimag, western Mongolia," PLoS One, vol. 9, Article ID e102892, 2014.

[24] International Union for Conservation of Nature (IUCN), The IUCN Red List, International Union for Conservation of Nature (IUCN), Gland, Switzerland, 2020, https://www.iucn.org/.

[25] Australian Government, Department of the Environment, 2019, http://www.environment.gov.au/system/files/resources/ e48702f7-b054-4a8a-b681-82f46531c0e1/files/factsheetwetlands-biodiversity.pdf.

[26] M. M. Iqbal, S. Nasren, M. A. A. Mamun, and M. M. Hossain, "Fish assemblage including threatened species in Hakaluki Haor, Sylhet Bangladesh," Journal of agriculture in the topics, vol. 30, pp. 233-246, 2015.

[27] K. Brajendu, K. Satendra, B. Auroshree et al., "Present status, abundance and threats of fish diversity on ramsar site (East Kolkata wetlands) of West Bengal, India," International Journal of Current Microbiology and Applied Sciences, vol. 7, pp. 4000-4007, 2018.

[28] N. K. Chowdhury, M. Ahmed, L. Rahman, M. Das, N. A. B. Bhuiyan, and G. S. Ahamed, "Present status of fish biodiversity in wetlands of Tahirpur Upazila under Sunamganj district in Bangladesh," International Journal of Fisheries and Aquatic Studies, vol. 6, pp. 641-645, 2018.

[29] M. A. Islam, M. J. Islam, S. K. Barman, F. Morshed, and S. S. Marine, "Study on present status of fish biodiversity in wetlands of sylhet district, Bangladesh," Agriculture, Forestry and Fisheries, vol. 4, no. 6, pp. 296-299, 2015.

[30] Red List of Bangladesh, Freshwater Fishes. 5, International Union for Conservation of Nature Bangladesh Country Office, Dhaka, Bangladesh, 2015.

[31] D. Dudgeon, A. H. Arthington, M. O. Gessner et al., "Freshwater biodiversity: importance, threats, status and conservation challenges," Biological Reviews, vol. 81, no. 2, pp. 163-182, 2006.

[32] IUCN, 2019, https://www.iucn.org/content/wetland-alienscause-bird-extinction.

[33] Red List of Bangladesh, Birds. 3, International Union for Conservation of Nature Bangladesh Country Office, Dhaka, Bangladesh, 2015b.

[34] A. S. Hamidu, D. S. Deo, J. C. M. Colin, M. Rob, and K. T. M. Pantaleo, "The impact of land use and land cover change on biodiversity within and adjacent to Kibasira Swamp in Kilombero Valley, Tanzania," African Journal of Ecology, vol. 56, pp. 518-527, 2017.

[35] S. Karki, A. M. Thandar, and K. Uddin, "Impact of land use and land cover change on ecosystem services: a comparative analysis on observed data and people's perception in Inle Lake, Myanmar," Environmental Systems Research, vol. 7, p. 25, 2018.

[36] S. A. R. Mucova, W. L. Filho, U. M. Azeiteiro, and M. J. Pereira, "Assessment of land use and land cover changes 
from 1979 to 2017 and biodiversity \& land management approach in Quirimbas National Park, Northern Mozambique, Africa," Global Ecology and Conservation, vol. 16, Article ID e00447, 2018.

[37] United Nations Environment Programme (UNEP), United Nations Environment Programme (UNEP) towards a Green Economy: Pathways to Sustainable Development and Poverty Eradication (2011) Report, United Nations Environment Programme, Nairobi, Kenya, 2011.

[38] A. Mei, C. Manzo, G. Fontinovo, C. Bassani, A. Allegrini, and F. Petracchini, "Assessment of land cover changes in Lampedusa Island (Italy) using Landsat TM and OLI data," Journal of African Earth Sciences, vol. 122, pp. 15-24, 2016.

[39] L. Brussaard, P. Caron, B. Campbell et al., "Reconciling biodiversity conservation and food security: scientific challenges for a new agriculture," Current Opinion in Environmental Sustainability, vol. 2, no. 1-2, pp. 34-42, 2010.

[40] J. Pretty, "Intensification for redesigned and sustainable agricultural systems," Science, vol. 362, p. 6417, 2018.

[41] C. S. Qu, W. Chen, J. Bi, L. Huang, and F. Y. Li, "Ecological risk assessment of pesticide residues in Taihu Lake wetland, China," Ecological Modelling, vol. 222, pp. 287-292, 2011.

[42] S. J. Butler, D. Brooks, R. E. Feber, J. Storkey, J. A. Vickery, and K. Norris, "A cross-taxonomic index for quantifying the health of farmland biodiversity," Journal of Applied Ecology, vol. 46, pp. 1154-1162, 2009.

[43] M. Dumortier, B. L. De, M. Hens et al., Biodiversity Indicators State of Nature in Flanders (Belgium), Research Institute for Nature and Forest, Brussels, Belgium, 2007.

[44] S. T. Mereta, A. Ambelu, A. Ermias et al., "Effects of untreated industrial effluents on water quality and benthic macroinvertebrate assemblages of Lake Hawassa and its tributaries, Southern Ethiopia," African Journal of Aquatic Science, vol. 45, pp. 285-295, 2020.

[45] P. Peduzzi, R. Harding, J. Richard, S. Kluser, L. Duquesnoy, and Boudol, UNEP Foresight Process: Phase I: Results of the UNEP Consultation, United Nations Environment Program, Nairobi, Kenya, 2011. 